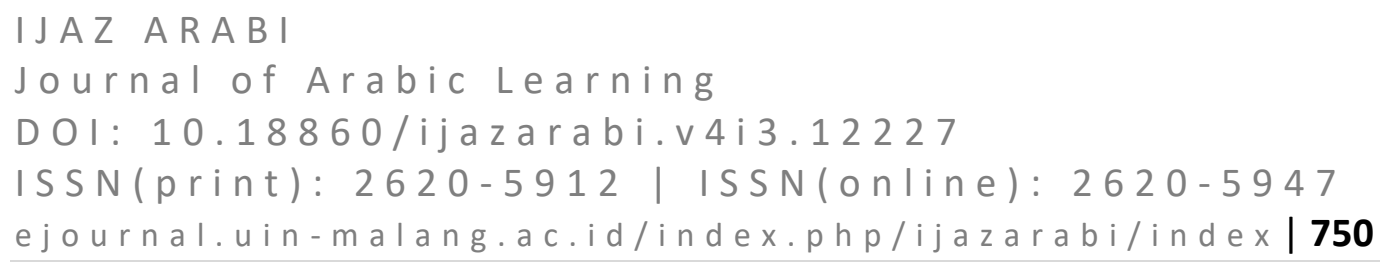

\title{
Language Learning Strategies And Readability Of Form Four KBD Arabic Textbooks
}

\author{
Mohd Fadzli Ismail ${ }^{1}$, Nik Mohd Rahimi Nik Yusoff ${ }^{2}$ \\ Universiti Kebangsaan Malaysia, Selangor, Malaysia ${ }^{1,2}$ \\ fadzli@ukm.edu.my ${ }^{1}$,nik@ukm.edu.my ${ }^{2}$
}

\begin{abstract}
There have been efforts to empower the Arabic language as a subject with the potential to strengthen the Early Integrated Curriculum (KBD) in Malaysia. The importance of mastering this subject is also emphasized in the Malaysian Education Development Plan (2013-2025). Thus, the need to examine language learning strategies with students' text readability is relevant. However, studies related to the readability of Arabic texts have been found to be limited and there are still weaknesses of students in using language learning strategies. Thus, this study aims to identify the relationship between language learning strategies and the readability of form four KBD Arabic textbooks among Government Aided Religious Schools (SABK) students. The Schema theory and the Interactive Reading Model by Rumelhart (1977) were used as the basis of this study. Meanwhile, quantitative design by survey was implemented on 694 students in five zones of SABK using the proportional strata random sampling technique. Data were analyzed descriptively and inferentially covering frequency, percentage, mean, standard deviation, Pearson correlation tests, and Kuder Richardson 20. The results of the study showed that the language learning strategies were at a moderate level. On the other hand, the level of readability of the Arabic textbooks of the students was disappointing. There was a weak significant positive relationship between language learning strategies and readability of form four KBD Arabic textbooks among SABK students. The implications of the study contributed to the applicability of the theories and models underpinned in the context of this study. The results of the study can also be used by teachers to help students improve their language learning strategies as well as to increase the readability achievement.
\end{abstract}

Keywords: Readability; Language Learning Strategies; Al-Lughah Al-Arabiah AlMuasirah; Early Integrated Curriculum; SABK Students

\section{INTRODUCTION}

The Early Integrated Curriculum or called Kurikulum Bersepadu Dini (KBD) introduced by the Ministry of Education Malaysia is a combination of the existing National Curriculum that has been implemented since 2015. This curriculum is based on the Malaysian Education Development Plan 2013-2025 stating that MOE is committed to providing high quality religious education to complement students with the relevant knowledge and skills to succeed in the job market based on strong Islamic values and philosophy. Moreover, this plan also strengthens the implementation of the national curriculum in religious schools by 
Journal of Arabic Learning

DOI: $10.18860 / \mathrm{ijazarabi.v4i3.12227}$

ISSN(print): $2620-5912$ | ISSN(onIine): $2620-5947$

ejournal.uin-malang.ac.id/index.php/ijazarabi/index/

raising the Dini and Tahfiz Curriculum as the National Curriculum while incorporating religious elements into the curriculum (Malaysia Education Ministry, 2013).

KBD was built by the Ministry of Education Malaysia (MOE), the Advisory Agency for the Streamlining Islamic Education and Islamic Studies or called Lembaga Penasihat Penyelarasan Pelajaran dan Pendidikan Agama Islam (LEPAI), and religious departments or foundations based on the Arabic-religious curriculum in religious schools in Malaysia comprising of two schools, namely Sekolah Agama Rakyat (SAR) and Sekolah Agama Negeri (SAN), registered as Government Aided Religious School or called as Sekolah Agama Bantuan Kerajaan (SABK). The main goal of the establishment of this curriculum is to provide balanced and excellent students based on naqli and 'aqli to prepare future scholars and religious muthaqqaf in the future. Besides, this is an effort to elevate and strengthen the teaching and learning process of KBD in schools, polish the potential and ability of students, and coordinate the KBD management system between KPM and the national curriculum (Islamic Education Division, 2015).

Accordingly, in strengthening the path of religious education in line with the new curriculum, the mastery of Arabic as an additional language needs to be improved comprehensively among students. The use of Arabic as the most important second additional language after English is seen to be more focused on teaching and learning activities that involve knowledge, skills, and reading materials. In this process, the reader needs to have the skills to understand the sentence order as well as the meaning of each word found in the reading material (Sjahrony, Lubis \& Yusoff, 2017; Samah, 2009). In the process of readability skills, Rahman et al. (2014) divide the reading process in Arabic texts into three stages starting with the beginning, intermediate, and advanced stages. Each of these levels is introduced according to the appropriateness of the students' level to receive and apply the language acquired in daily life. These curriculum changes have made textbooks a source to determine the level of mastery of students in the ability to read, understand, and apply existing knowledge through examinations scheduled based on the syllabus coordinated by the MOE. Textbooks prepared according to Hamjah et al. (2010) and Ghani (2011) require appropriate skills and levels of reading ability for students to master while being able to attract their interest and motivation to continue using it in learning a foreign language. KBD subjects, which use Arabic as the medium of instruction and learning, use Arabic textbook alLughah al-Arabiah al-Muasirah form four, and are different according to the level of learning at the lower and upper secondary levels which include the field of alIstima 'wa al-Kalam, al-Qiraah, al-Kitabah, al-Mutalaah wa al-Ta'bir, and alNahu wa al-Sarf.

The language learning strategy is an action taken by students that would help them understand, remember, and produce activities to manage language learning that covers all types of language skills in learning (Chamot, 1998; Chamot et al., 1999). The use of these strategies is supposed to be more effective and 
appropriate while making learning sessions more interesting, enjoyable, and can be improved according to current circumstances, and believed to be an important factor in determining student success (Marsh et al., 2006; Zimmerman \& MartinezPons, 1990; Oxford, 1990). Oxford (1990) states that various language learning strategies that can be used by students when learning a language are also influenced by cognitive, metacognitive, affective, social, psychological, and other factors.

However, some of the problems detected in the readability of textbooks include too little effort to measure the level of readability of reading materials used as subject text. This has been going on for so long that students' reading ability is questionable because most teachers adopt a one-way teaching approach and think that students are not able to carry out self-learning (Samah, 2008) in addition to weaknesses in using language learning strategies (Yusoff \& Ghani, 2008). This is because some excellent students are unable to share their experiences with others regarding the proper use of these strategies and some of the strategies used cannot be closely observed even by the language teachers (Bialystok, 1985; O'Malley et al., 1985; Oxford \& Crookall, 1989; Park, 1997). As a result, there are weaknesses in the use of language learning strategies by students that contrast with the strategies used by teachers.

This has left a gap in the content of Arabic textbooks which is less effective with the existing ability of students to master, and it has prompted this readability study to be implemented. Accordingly, this study should be conducted to measure the level of ease and difficulty of KBD Arabic textbooks at the upper secondary level. In the context of textbook readability, the Schema theory and the Interactive Reading Model by Rumelhart (1977) were used as the basis in this study. Among the schemata, concepts are ideas that describe the mental framework for and formation of memory such as views that express knowledge designed by students when they face new situations and levels of processing, for instance, the notion that memory is a by-product of received information. Moreover, through this model, the reader will use both concepts of reading; reading top to bottom and bottom to top, simultaneously (Ghani, 2003; Urquhart \& Weir, 1998).

The main objective of this research is to determine the level of readability of the KBD Arabic textbook and its suitability for SABK students. It can also be used as a basis and guide toward publishing KBD Arabic textbooks easily and relevant for the use of students who are learning Arabic as a second language. Thus, this study aims to identify the level of language learning strategies and their relationship with the readability of form four KBD Arabic textbooks among SABK students.

\section{METHOD}

A descriptive quantitative study was employed to empirically determine the readability of the form four KBD Arabic textbook by using proportional strata random sampling technique to obtain the perceptions of form four students at SABK while answering the language learning strategies questionnaire on the 
readability of form four KBD Arabic textbooks. The population of this study consisted of form four students who took KBD Arabic language subjects at SABK which represented a total of 694 students in five zones, namely North, South, West, East, and East Malaysia. The variable of questionnaire for language learning strategies contained 27 items in questionnaire form and was modified and adapted from the Strategy Inventory for Language Learning (SILL) V.7.0 questionnaire by Oxford (1990). This section covers the domains of memory, metacognitive, cognitive, and support in mastering Arabic to the readability of the form four KBD Arabic textbooks. The cloze test was used to obtain data from students related to the reliability of form four KBD Arabic textbooks, containing three texts of 14 topics from form four KBD Arabic textbook (al-Lughah al-Arabiah al-Muasirah) that were randomly selected.

This study involved descriptive and inferential analysis to answer the objective of this study that has been formed. Descriptive statistics were used in the form of frequency, percentage, mean, and standard deviation. To answer the question of language learning strategies involving descriptive analysis, a 5-point Likert scale was developed and divided into 3 categories; namely Not True (scale for $1=$ very not true, and $2=$ not true), Almost True (scale for $3=$ almost true), and True (scale for $4=$ true, and $5=$ very true). The level of each variable was measured according to the interpretation of the mean score by Pallant (2010) where the score value of 1.00 to 2.33 was at a low level, the score value of 2.34 to 3.67 was at a moderate level, and the score value of 3.68 to 5.00 was at a high level.

The measurement of readability score in the analysis was based on the table of measurement of readability score by Rye (1982) where the answer score between 0 and 74 was categorized as disappointing. The score value between 75 and 89 was at the teaching level, and the score value between 90 and 100 was explained as independent level. The inferential analysis allowed the researcher to decide when determining the generalization of the selected sample data. Correlation analysis was used to answer the question of the relationship between language learning strategies with the readability of form four KBD Arabic textbooks through Pearson correlation coefficient $(r)$ in the form of interval or ratio data.

\section{RESULTS AND DISCUSSION}

The results and discussion for the objective on the level and relationship between language learning strategies and the readability of the textbook are as follows.

\section{Level of Language Learning Strategies Among SABK Students}

Table 1 shows the results of the highest frequency and percentage of the 27 items of language learning strategies. The overall mean score value of the language learning strategies is 3.43 with a standard deviation of 0.54 . The results of the study for the language learning strategies among SABK students are at a moderate level by taking into account the recommendations of interpretation by Pallant (2010). 


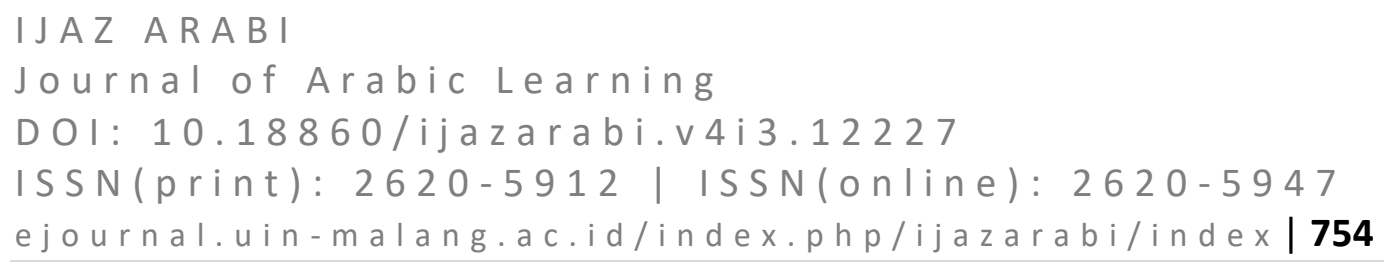

These results are in line with the studies by al-Otaibi (2004), Teh et al. (2009), Lai (2005), Embi et al. (2001), and Rashid (2003) who obtain the same level position for students' language learning strategies. This means that SABK students need to use strategies either inside or outside the classroom because they play an important role for non-Arabic speakers. These results have also been agreed by other researchers including Lai (2009), Li and Chun (2012), Macaro (2001), Adnan and Mohamad (2011), as well as Qiufang and Lifei (2004).

In detail, the results show $77 \%$ of students most often ask a more knowledgeable friend to explain the meaning of a text when it is difficult to understand (item 26). They also often think in Malay to understand the Arabic text in item 4 (73\%). In this case, cultural factors and technique selection in language learning strategies can influence a student's level of readability. This view has been agreed by Nafi and Teh (2014), Kuntz (1996), Rouyan (2006), and Hamid (1994). Indirectly, high awareness and motivation in students also play an important role in determining the strategies to be adopted in learning Arabic in school. This approach is found to be appropriate because it supplies students with an extensive vocabulary and trains them to conclude the text read.

The results also report that less than $50 \%$ of students speak on their own and use motivational words to lift spirits in Arabic (item 19). Gardner (1983) found that attitude is a determining factor in a student's success in mastering second language learning. The attitude of hating each other and looking down on a language makes it difficult for the reader or student to master the learning of a second language (Abdullah, 2002). This is because students who are negative use fewer effective strategies for second language learning as stated in the study by Mahamod and Othman (2001). Lack of proper language learning strategies such as lack of bookreading activities or lack of communication among peers is the factor that contributes to negative attitudes toward language learning.

The results found that more than $50 \%$ of students do not create a specific timetable for reading Arabic materials (item 11). Teachers' teaching factors in the classroom influence students' interest and motivation to master the readability of Arabic texts. This means that teachers need to expose students to plan a schedule for reviewing subjects after school hours. This is agreed by Ahmad (1985) who suggests that language learning strategies start with smaller things, then to broader things and something more specific later on, and elaborate on more general things. The teachers need to apply elements of self-regulation and coping skills to students in the classroom as agreed by Ali, Abdullah, and Rahman (2019). Thus, students can learn independently to be proficient in the readability of Arabic texts. Selforganization can improve a student's achievement with the help of teachers through the provision of better-quality self-directed student learning materials. A suitable learning environment should be provided by the school so that students can benefit and use coping skills more effectively.

Therefore, the use of language learning strategies in the language learning process is very important to students. If used correctly, the strategies can improve 
Journal of Arabic Learning

DOI: $10.18860 / \mathrm{ijazarabi.v4i3.12227}$

ISSN(print): $2620-5912$ | ISSN(onIine): $2620-5947$

ejournal.uin-malang.ac.id/index.php/ijazarabi/index/

students' readability in learning a second language, namely Arabic. Teh and Embi (2010) as well as Mahamod (2015) state that students who regularly practice such strategies with various techniques are more successful in mastering the target language. Mahamod et al. (2002) also state that students should master this strategy according to the comfort of their learning style which contributes to the improvement of their achievement in examinations.

Table 1: Language learning strategies

\begin{tabular}{|c|c|c|c|c|}
\hline & \multirow{2}{*}{ Item } & $\begin{array}{l}\text { Not } \\
\text { True }\end{array}$ & $\begin{array}{c}\text { Almost } \\
\text { True }\end{array}$ & True \\
\hline & & $\begin{array}{c}\mathbf{n} \\
(\%)\end{array}$ & $\begin{array}{c}\mathbf{n} \\
(\%)\end{array}$ & $\begin{array}{c}\mathbf{n} \\
(\%)\end{array}$ \\
\hline 1 & I read the Arabic text carefully. & $\begin{array}{c}44 \\
(6.3)\end{array}$ & $\begin{array}{c}244 \\
(35.2)\end{array}$ & $\begin{array}{c}406 \\
(58.5)\end{array}$ \\
\hline 2 & $\begin{array}{l}\text { I often mention over and over again the new } \\
\text { words I learned. }\end{array}$ & $\begin{array}{c}90 \\
(13.0)\end{array}$ & $\begin{array}{c}284 \\
(40.9)\end{array}$ & $\begin{array}{l}320 \\
(46.1)\end{array}$ \\
\hline 3 & $\begin{array}{l}\text { I always use a dictionary to understand } \\
\text { Arabic words. }\end{array}$ & $\begin{array}{l}63 \\
(9.1)\end{array}$ & $\begin{array}{c}204 \\
(29.4)\end{array}$ & $\begin{array}{c}427 \\
(61.5)\end{array}$ \\
\hline 4 & $\begin{array}{l}\text { I often think in the Malay language to } \\
\text { understand the Arabic text. }\end{array}$ & $\begin{array}{c}39 \\
(5.6)\end{array}$ & $\begin{array}{c}147 \\
(21.2)\end{array}$ & $\begin{array}{c}508 \\
(73.2)\end{array}$ \\
\hline 5 & $\begin{array}{l}\text { I always use additional reading material as a } \\
\text { reference in learning Arabic. }\end{array}$ & $\begin{array}{c}186 \\
(26.8)\end{array}$ & $\begin{array}{c}281 \\
(40.5)\end{array}$ & $\begin{array}{c}227 \\
(32.7)\end{array}$ \\
\hline 6 & $\begin{array}{l}\text { I make assumptions about the meaning of } \\
\text { new words read based on existing knowledge. }\end{array}$ & $\begin{array}{c}102 \\
(14.7)\end{array}$ & $\begin{array}{l}275 \\
(39.6)\end{array}$ & $\begin{array}{c}317 \\
(45.7)\end{array}$ \\
\hline 7 & I try to translate newly learned Arabic words. & $\begin{array}{c}48 \\
(6.9)\end{array}$ & $\begin{array}{c}222 \\
(32.0)\end{array}$ & $\begin{array}{c}424 \\
(61.1)\end{array}$ \\
\hline 8 & $\begin{array}{l}\text { I combine new knowledge with existing } \\
\text { knowledge in Arabic reading. }\end{array}$ & $\begin{array}{c}99 \\
(14.3)\end{array}$ & $\begin{array}{c}241 \\
(34.7)\end{array}$ & $\begin{array}{c}354 \\
(51.0)\end{array}$ \\
\hline 9 & I always re-read the text to help to understand. & $\begin{array}{c}87 \\
(12.6)\end{array}$ & $\begin{array}{c}213 \\
(30.7)\end{array}$ & $\begin{array}{c}394 \\
(56.7)\end{array}$ \\
\hline 10 & $\begin{array}{l}\text { I am looking for as many appropriate } \\
\text { techniques to improve the quality of Arabic } \\
\text { language learning. }\end{array}$ & $\begin{array}{c}106 \\
(15.3)\end{array}$ & $\begin{array}{c}282 \\
(40.6)\end{array}$ & $\begin{array}{c}306 \\
(44.1)\end{array}$ \\
\hline 11 & $\begin{array}{l}\text { I made a special timetable for the reading of } \\
\text { Arabic material. }\end{array}$ & $\begin{array}{c}348 \\
(50.1)\end{array}$ & $\begin{array}{c}242 \\
(34.9)\end{array}$ & $\begin{array}{c}104 \\
(15.0)\end{array}$ \\
\hline 12 & I set goals while reading textbooks. & $\begin{array}{c}245 \\
(35.3)\end{array}$ & $\begin{array}{c}279 \\
(40.2)\end{array}$ & $\begin{array}{l}170 \\
(24.5)\end{array}$ \\
\hline 13 & $\begin{array}{l}\text { I made a self-assessment to ensure the level } \\
\text { of comprehension in Arabic reading. }\end{array}$ & $\begin{array}{c}185 \\
(26.7)\end{array}$ & $\begin{array}{c}285 \\
(41.1)\end{array}$ & $\begin{array}{c}224 \\
(32.3)\end{array}$ \\
\hline 14 & $\begin{array}{l}\text { I compared the level of Arabic reading } \\
\text { comprehension with my classmates. }\end{array}$ & $\begin{array}{c}144 \\
(20.7)\end{array}$ & $\begin{array}{c}234 \\
(33.7)\end{array}$ & $\begin{array}{c}316 \\
(45.5)\end{array}$ \\
\hline
\end{tabular}


15 I evaluated the techniques used during Arabic reading to make improvements.

$\begin{array}{ccc}118 & 299 & 277 \\ (17.0) & (43.1) & (39.9) \\ 128 & 303 & 263 \\ (18.5) & (43.7) & (37.9)\end{array}$
Arabic.

$245 \quad 261 \quad 188$

17 I don't pay attention to difficult words in the process of reading.

(35.3) (37.6) (27.1)

18 I often talk to myself to lift my spirits in $148 \quad 229 \quad 317$ Arabic reading.

$(21.3) \quad(33.0) \quad(45.7)$

19 I often post motivational words to uplift the $\begin{array}{llll}186 & 224 & 284\end{array}$ spirits in learning Arabic.

$(26.8) \quad(32.3) \quad(41.0)$

20 I often persuade myself to get rid of anxiety $94 \quad 203 \quad 397$ when having difficulty reading Arabic.

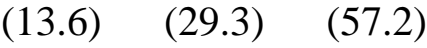

21 I often ask for advice to increase my interest in reading Arabic.

$121 \quad 238 \quad 335$

$(17.5) \quad(34.3) \quad(48.3)$

22 I often ask for advice to get rid of anxiety when having difficulty reading Arabic.

$129 \quad 239 \quad 326$

(18.6) (34.4) (47.0)

23 I work in groups to strengthen my $97 \quad 194 \quad 403$ understanding of Arabic reading.

$\begin{array}{lll}(14.0) \quad(28.0) \quad(58.0) & (20)\end{array}$

24 I often talk to a friend after reading a new word.

$111 \quad 207 \quad 376$

$(16.0) \quad(29.8) \quad(54.2)$

25 I often ask teachers when they have difficulty reading Arabic.

$92 \quad 233 \quad 369$

(13.3) (33.6) (53.1)

26 I always ask a more knowledgeable friend to

$35 \quad 128 \quad 531$
explain the meaning of a text when it is (5.1) (18.4) (76.6) difficult to understand.

27 I asked someone to correct a mistake while $\quad 86 \quad 190 \quad 418$ reading.

(12.4) (27.4) (60.2)

Mean $=3.43$, Standard deviation $=0.54$, Level $=$ Moderate

\section{Level of Readability of the Form Four Textbook Among SABK Students}

Table 2 shows the level of readability of the form four KBD Arabic textbooks through three cloze test texts. Based on the table, the mean readability score of Text $\mathrm{B}$ is higher than Text $\mathrm{C}$ and Text $\mathrm{A}$ with a mean value of 24.71 or $25 \%$ of the readability score. Text $\mathrm{C}$ shows a mean score value of 22.05 or $22 \%$ of readability score, while Text A only shows a mean score of 17.95 or $18 \%$ of readability score. The overall readability score of the form four KBD Arabic textbook is 21.57 with a standard deviation of 6.46 . Thus, the overall readability score is $22 \%$, which is at a frustrating level (Rye, 1982).

This illustrates that the form four KBD Arabic textbook level four has reached a level of difficulty that exceeds the level of students' ability to master and understand the reading material. Indirectly, the form four KBD Arabic textbook is less suitable to be used as a reading material for students. These results are similar to the study done by Ghani (2010), Husaini et al. (2014), and Halim (2012) in their 
IJAZ ARABI

Journal of Arabic Learning

DOI: $10.18860 / \mathrm{ijazarabi.v4i3.12227}$

ISSN(print): $2620-5912$ | ISSN(onIine): $2620-5947$

ejournal.uin-malang.ac.id/index.php/ijazarabi/index /

studies on the level of readability of Arabic textbooks. The results of the cloze test conducted by these two studies found that the overall level of readability is still at a disappointing level although the value in their study is quite high compared to the results of this study. The results by Arifin et al. (2013, 2012) on the level of readability of Arabic Literature texts also show that the level of readability of students toward the text is at a disappointing level.

Table 2: Textbook readability level

\begin{tabular}{rcc}
\hline Texts & Mean & Standard deviation \\
\hline Text A & 17.95 & 4.91 \\
Text B & 24.71 & 8.73 \\
Text C & 22.05 & 7.81 \\
\hline Total Score & $\mathbf{2 1 . 5 7}$ & $\mathbf{6 . 4 6}$ \\
\hline
\end{tabular}

The results of this frustrating readability level analysis are in line with the explanations of studies by Yusoff (1999), Gillet and Temple (1994), and Ghani (2010). Students in this level often consider the form four KBD Arabic textbooks to be too difficult. That means students in this level have a poor level of reading comprehension, are not fluent, and there are too many words that need to be analyzed before the reading activity begins. Besides, students who are at this level also have no appropriate reading for the learning task, and reading is done only for learning and can only be done if the students themselves have a high level and interest in the reading material.

\section{The Relationship Between Language Learning Strategies and the Readability of Form Four KBD Arabic Textbooks}

Table 3 shows the results of the analysis of the relationship between the technical presentation of the textbook and the readability of the form four KBD Arabic textbooks. The value of the Pearson correlation coefficient obtained is $r=$ 0.163 , which indicates the existence of a weak positive relationship. Thus, there is a significant weak relationship between the language learning strategies with the readability of the form four KBD Arabic textbooks $(r=0.163, p<0.05)$. This result is in line with the study by Teh et al. (2009), stating that there is a linear relationship between the level of Arabic language proficiency with the use of language learning strategies.

Furthermore, Green and Oxford (1995) as well as Griffith (2003) also state that the use of frequent, correct, and appropriate language learning strategies by readers provides results to the existence of a significant relationship with language performance excellence. This proves that language learning strategies play a very important role in the activation process of a reader. These results are further reinforced by a study by Prodromou as noted by Jabeen et al. (2013) that students' attitudes are important because language learning success has a correlation with students' positive attitudes toward the language and the culture of the language. 
In line with that, the use of translation of reading material in language learning strategies is also explained in the study by Mustaffar (2003). His study found that the use of translating method is still widespread and the findings on this strategy are at a high level. A study by Samah (2009) also shows that teaching in religious schools is more focused on translation method because the subjects are taught in Arabic. Thus, teachers take the easy way to give understanding to students by translating one by one.

However, according to Yusoff and Ghani (1999), such method can impair the understanding of meaning in lesson content. This is because the use of translation method is very important to provide comprehension to students, but the widespread use of such method has resulted in low mastery of students' readability level (Mustaffar, 2003). Moreover, Lado (1988) states that the weakness of the translation method stems from the translation training practiced in the classroom which has been misunderstood when it assumes the same as comprehension, speaking, reading, and writing. This can be illustrated by mistakes in using language learning strategies that can eventually lead to decreased learning performance.

Besides, failure to apply language learning strategies to readability can invite a decline in student performance. This supports the study by Lubis et al. (2014) and Daud et al. (2012) who found that the level of use of teaching aids of alAzhar Curriculum teachers is low. The use of ICT-oriented materials is not the choice of teachers when implementing the teaching and learning process (Lubis et al., 2014; Samah, 2009). This result is also similar to the study by Muhammad (2006) who found that the use of Arabic words while teaching is at an unsatisfactory level, supported by a study by Daud and Muhammad (2003), which is $75 \%$ of teachers use the Malay language in teaching and learning al-Azhar Curriculum in the classroom.

The study also found that the use of textbooks and notes is the main source for teachers compared to other sources of material (Lubis et al., 2014). Teachers do not disclose to students the sources of materials that can be obtained from the internet which is the main source for obtaining reading materials (Samah, 2009). As a result of such practices, the students involved are more dependent on the materials used by the teacher alone (Daud \& Muhammad, 2003). Consistent with the results of the analysis of this study, language learning strategies are found to have a weak and significant positive relationship with the readability of form four KBD Arabic textbooks, showing that students need to use language learning strategies well and often used in understanding and mastering readability textbooks, while teachers need to intensify efforts in helping students improve their understanding of the readability of form four KBD Arabic textbooks.

Table 3: Relationship between language learning strategies and readability

\begin{tabular}{lccc}
\hline Variable & r & Sig. & Relationship strength \\
\hline Language Learning Strategies & 0.163 & 0.000 & weak \\
\hline
\end{tabular}




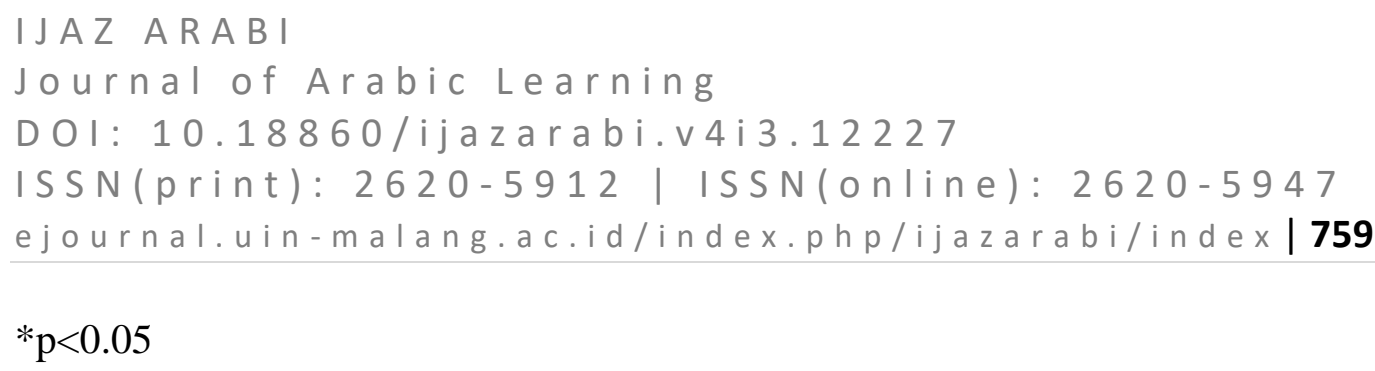

\section{CONCLUSION}

Overall, this study discusses the results of the analysis of the relationship between language learning strategies and readability of form four KBD Arabic textbooks among students in SABK. The results of the analysis for this study conclude that teachers can select additional learning materials in the teaching and learning of students in appropriate classrooms and schools, and be able to attract students to participate in them. The readability-strengthening activity materials such as quizzes, crossword puzzles, two-way interactions, and more, such as for group work materials, and the use of multimedia materials according to knowledge level can indeed help build students' self-confidence in reading Arabic materials.

The results of language learning strategies on readability can be validated based on the Schema theory and the Interactive Reading Model by Rumelhart (1977). Moreover, the results of the study can also be used by teachers to help students improve their language learning strategies as well as to increase the achievement of readability, and so on, as well as expected to provide information and guidance that can be utilized by future researchers. Some implications of the language learning strategies on the readability of form four KBD Arabic textbooks are expected to help in the improvement in the results of future studies.

\section{REFERENCES}

Abdullah, N.H. (2002) Sikap dan motivasi dalam pembelajaran bahasa kedua. [Attitudes and motivation in second language learning]. Dewan Bahasa, pp. 45-47.

Adnan, M.A.M., \& Mohamad, S. (2011). Language learning strategies and selfefficacy belief in Arabic language learning: A Malaysian context. ASEAN Journal of Teaching \& Learning in Higher Education, 3(2), 48-59.

Ahmad, M.A.Q. (1985). Turuq Ta'lim al-Tarbiyah al-Islamiyah. t.tp: Maktabah alNahdhah al-Misriyah.

Ali, N., Abdullah, M.H., \& Rahman, A.A. (2019). Keberkesanan modul pembelajaran kendiri strategi pemahaman membaca teks bahasa Arab (MPK SPMBA) untuk pelajar pengajian Islam di Institusi Pengajian Tinggi. [Effectiveness of self -learning module of Arabic text reading comprehension strategy (MPK SPMBA) for Islamic studies students in Institutions of Higher Learning]. Proceeding of the International Conference on Islamic Civilization and Technology Management, pp. 722-739.

al-Otaibi, G.N. (2004). Language learning strategy use among Saudi EFL students and its relationship to language proficiency level, gender, and motivation. Unpublished doctoral dissertation, Indiana University of Pennsylvania, USA.

Arifin, Z., \& Sham, N.M.M. (2012). Kebolehbacaan buku teks prosa Arab dalam kalangan pelajar pascasiswazah, Fakulti Pengajian Islam, Universiti 
Journal of Arabic Learning

DOI: $10.18860 / \mathrm{ijazarabi.v4i3.12227}$

ISSN(print): $2620-5912$ | ISSN(onIine): $2620-5947$

ejournal.uin-malang.ac.id/index.php/ijazarabi/index/ 760

Kebangsaan Malaysia. [Readability of Arabic prose textbooks among postgraduate students, Faculty of Islamic Studies, Universiti Kebangsaan Malaysia] Kertas Kerja Persidangan Kebangsaan Pengajaran dan Pembelajaran Bahasa Arab 2012.

Arifin, Z., Bakar, K.A., \& Ahmad, M. (2012). Kebolehbacaan teks Sastera Arab dalam kalangan pelajar Jabatan Pengajian Arab dan Tamadun Islam, Fakulti Pengajian Islam UKM. [Readability of Arabic Literature texts among students of the Department of Arabic Studies and Islamic Civilization, Faculty of Islamic Studies UKM.] Prosiding Seminar Pemantauan Projek Penyelidikan Tindakan Strategik (PTS) Fakulti Pengajian Islam.

Arifin, Z., Halim, Z.A., Sham, N.M.M., \& Shukry, A.S.M. (2013). The readability of the Arabic prose text. Middle-East Journal of Scientific Research, 17(3), 338-343.

Bialystok, E. (1985). The compatibility of teaching and learning strategies. Applied Linguistics, 6: 255-262.

Chamot, A. U., Bernhardt, S., El-Dinary, P. B. \& Robbins, J. (1999). The learning strategies handbook. White Plains, NY: Addison Wesley Longman.

Chamot, A.U. (1998). Teaching-learning strategies to language students. Washington, DC: Center for Applied Linguistics.

Daud, M.M., \& Muhammad, K.K. (2003). Permasalahan pengajaran dan pembelajaran Kurikulum Al-Azhar dan cara mengatasinya. [Problems of teaching and learning Al-Azhar Curriculum and how to overcome them.]. Prosiding Wacana Pendidikan Islam (Siri 3). Royal Adelphi, Seremban, 16 October.

Daud, Z., Adi, M.F.A., \& Abdullah, M. (2012). Kaedah pengajaran dan pembelajaran pengajian Qira'at di Jabatan Al-Quran dan Al-Qira'at, KUIS: Satu tinjauan awal. [Methods of teaching and learning the study of Qira'at in the Department of Al-Quran and Al-Qira'at, KUIS: A preliminary survey.]. Proceeding ICEARIALE International Conference on Research in Islamic and Arabic Language Education. Elaf Kinda Hotel, Mekah, 1-2 June.

Embi, M.A., Mahamod, A., \& Bakar, M.N.A. (2001). Pola penggunaan strategi pembelajaran bahasa Melayu. [ The pattern of use of the Malay language learning strategies]. Journal of Language Teaching Linguistic and Literature, 7, 95-109.

Gardner, H. (1983). Frames of mind: The theory of multiple intelligence. New York: Basic Books.

Ghani, K.A. (2010). Kebolehbacaan buku teks Bahasa Arab Tinggi tingkatan empat Sekolah Menengah Kebangsaan Agama. [Readability of Higher Arabic textbook form four Sekolah Menengah Kebangsaan Agama.] Doctoral dissertation. Universiti Malaya.

Ghani, K.A. (2011). Kebolehbacaan buku teks Bahasa Arab Tinggi berasaskan ujian Kloz dalam kalangan pelajar di SMKA. [Higher Arabic textbook 
Journal of Arabic Learning

DOI: $10.18860 / \mathrm{ijazarabi.v4i3.12227}$

ISSN(print): 2620-5912 | ISSN(online): 2620-5947

ejournal.uin-malang.ac.id/index.php/ijazarabi/index| $76 \mathbf{1}$

readability based on Kloz test among students in SMKA] GEMA Online ${ }^{\circledR}$ Journal of Language Studies, 11(2), 53-66.

Ghani, S.A. (2003). Al-Asma al-Mushtaqqat dalam bahasa Arab dan kata nama terbitan dalam bahasa Melayu: Satu kajian bandingan. [Al-Asma alMushtaqqat in Arabic and masculine publications in languages other than English: A comparative study.] Bachelor dissertation. Jabatan Pengajian Arab dan Tamadun Islam. Bangi: Universiti Kebangsaan Malaysia.

Gillet, J. W. \& Temple, C. (1994). Understanding reading problems. Journal of Adolescent and Adult Literacy, 66(4), 300-308.

Green, J. \& Oxford, R. (1995). A closer look at learning strategies, L2 proficiency, and gender. TESOL Quarterly, 29(2), 261-297.

Griffiths, C. (2003). Pattern of language learning strategy use. System 31, 367-383.

Halim, Z.A. (2012). Kebolehbacaan buku teks Balaghah Sijil Tinggi Agama Malaysia di sekolah-sekolah Menengah Agama Negeri. [Readability of Balaghah Sijil Tinggi Agama Malaysia textbook in State Religious Secondary schools.] Doctoral dissertation. Fakulti Pengajian Islam. Universiti Kebangsaan Malaysia.

Hamid, Z. (1994). Pembelajaran dan pengajaran bahasa. [Language learning and teaching]. Kuala Lumpur: Dewan Bahasa dan Pustaka.

Hamjah, S.H., Ismail, Z., Rasit, R.M., \& Rozali, E.A. (2010). Kaedah peningkatan motivasi belajar dalam kalangan pelajar Fakulti Pengajian Islam, UKM. [Methods to increase learning motivation among students of the Faculty of Islamic Studies, UKM] Kongress Pengajaran Pembelajaran UKM 2010, 1215 December.

Husaini, M.H., Rahman, M.S.A., Ghazali, A.R., \& Abdullah, N. (2014). Tahap kebolehbacaan buku al-Mursyid fi al-Lughah al-Arabiah. [The level of readability of the book of al-Mursyid fi al-Lughah al-Arabiah.] International Journal of Islamic Studies and Arabic Language Education, 1(1), 11-16.

Islamic Education Division. (2015). Maklumat Asas Pelaksanaan Kurikulum Bersepadu Dini. [Basic Information on Early Integrated Curriculum Implementation]. Malaysia Education Ministry.

Jabeen, F., Zahid, S., \& Sattar, A. (2013). Inclusion of Target Language Culture in EFL Classrooms in Pakistan: Learners' Perspective. Research on Humanities and Social Sciences, 3(18), 97-106.

Kuntz, P. (1996). Students of Arabic: Belief about foreign language learning. AlArabiyya, 29, 153-173.

Lado, R. (1988). ESL through Content-Area Instruction: Mathematics, Science, Social Studies, 93-94.

Lai, Y.C. (2005). Language learning strategy use and language proficiency for English as a Foreign Language Learner (EFL) in Taiwan. Unpublished doctoral dissertation, University of Southern California.

Lai, Y.C. (2009). Language learning strategy use and English proficiency of university freshmen in Taiwan. TESOL Quarterly, 43(2), 255-280. 


\section{IJAZ ARAB I}

Journal of Arabic Learning

DOI: $10.18860 / \mathrm{ijazarabi.v4i3.12227}$

ISSN(print): $2620-5912$ | ISSN(onIine): $2620-5947$

ejournal.uin-malang.ac.id/index.php/ijazarabi/index| 762

Li, J., \& Chun, C. K. (2012). Effects of learning strategies on student reading literacy performance. Reading, 12(1), 30-38.

Lubis, M.A., Alias, Z., \& Shaharuddin, H.N. (2014). Pelaksanaan pengajaran dan pembelajaran bahasa Arab dalam Kurikulum Bu'uth al-Azhar di Sekolah Agama Bantuan Kerajaan (SABK). [Implementation of teaching and learning of Arabic in the Bu'uth al-Azhar Curriculum in Government Aided Religious Schools (SABK).]. Jurnal Pendidikan Malaysia, 39(1), 51-61.

Macaro, E. (2001). Analysing students' teachers' codeswitching in Foreign Language Classrooms: Theories and decision making. The Modern Language Journal, 85, 531-548.

Mahamod, Z. (2015). Profisien murid dalam kemahiran Bahasa Melayu: Isu dan cabaran. [Students proficient in the Malay language skills: Issues and challenges]. Prosiding Seminar Pascasiswazah Pendidikan Bahasa Melayu dan Kesusasteraan Melayu Kali Ke-4, pp. 1-8. Fakulti Pendidikan UKM.

Mahamod, Z., \& Othman, Z. (2001). Sikap pelajar Cina terhadap pembelajaran Bahasa Melayu sebagai bahasa kedua. [Chinese students' attitudes toward learning English as a second language]. Dewan Bahasa, pp. 40-43.

Mahamod, Z., Embi, M.A., Ishak, N.M., \& Long, J. (2002). Strategi pembelajaran bahasa dari segi jantina pelajar cemerlang: Satu kajian perbandingan. [Language learning strategies in terms of the gender of outstanding students: A comparative study]. Proceedings of International Conference of Education for All, pp. 63-77.

Malaysia Education Ministry. (2013). Pelan Pembangunan Pendidikan Malaysia 2013-2025: Pendidikan Pra-sekolah hingga Lepas Menengah. [Malaysia Education Development Plan 2013-2025: Pre-School to Post-Secondary Education] Putrajaya, Malaysia: KPM.

Marsh, H.W., Hau, K.T., Artelt, C., Baumert, J., \& Peschar, J.L. (2006). OECD's brief self-report measure of educational psychology's most useful affective constructs: Cross-cultural, psychometric comparisons across 25 countries. International Journal Testing,6(4), 311-360.

Muhammad, A. (2006). Pembelajaran balaghah Arab di peringkat Sijil Tinggi Agama Malaysia: Satu kajian kes. [Learning Arabic balaghah at the Sijil Tinggi Agama Malaysia level: A case study]. Tesis Ijazah Sarjana. Universiti Malaya.

Mustaffar, R. (2003). Penggunaan kaedah nahu terjemahan dalam pengajaran bahasa Arab: Tinjauan di tiga buah Sekolah Agama Negeri Kelantan. [The use of translation grammar method in Arabic language teaching: A survey in three Kelantan State Religious Schools]. Master dissertation. Fakulti Pendidikan, UKM.

Nafi, L.M., \& Teh, K.S.M. (2014). Kepelbagaian penggunaan strategi pembelajaran bahasa Arab (SPBA) dalam kalangan pelajar IPT Kelantan. [Diversity of the use of Arabic language learning strategies (SPBA) among Kelantan IPT students]. The Online Journal of Islamic Education 
Journal of Arabic Learning

DOI: $10.18860 / \mathrm{ijazarabi.v4i3.12227}$

ISSN(print): $2620-5912$ | ISSN(online): $2620-5947$

ejournal.uin-malang.ac.id/index.php/ijazarabi/index| 763

O’Molley, J.M., Chamot, A.U., Stewner-Manzanares, G., Kupper, L., \& Russo, R. P. (1985). Learning strategies used by beginning and intermediate ESL students. Language Learning, 35(1), 21-46.

Oxford, R. L. (1990). Language Learning Strategies: What every teacher should know. New York: Newbury House Publisher.

Oxford, R., \& Crookall, D. (1989). Research on language learning strategies: Methods, findings, and instructional issues. Modern Language Journal, 73(4), 404-419.

Pallant, J. (2010). SPSS survival manual: A step-by-step guide to data analysis using the SPSS program. ( $4^{\text {th }}$ Edition). New York: McGraw Hill.

Park, G.E. (1997). Language learning strategies and English proficiency in Korean University students. Foreign Language Annals, 30, 211-221.

Qiufang, W., \& Lifei, W. (2004). Challenging the effectiveness of L2 learning strategy studies. Foreign Language World, 2, 2-7.

Rahman, A.A., Jamali, H.N., Ku Azizan, K.F., \& Bahri, N.S. (2014). Pengajaran dan pembelajaran kemahiran membaca bahasa Arab di KUIS. [Teaching and learning of Arabic reading skills in KUIS.] $4^{\text {th }}$ International Conference and Exhibition on Islamic Education (ICELd 2014), Kota Bharu, Kelantan.

Ramli, M.K.H., \& Mohamad, A.H. (2015). Tahap kekerapan dan kepadatan kosa kata buku teks Bahasa Arab Sekolah Rendah. [Level of frequency and vocabulary density of Primary School Arabic textbooks] Journal Pendidikan Bitara UPSI (JPBU), 7.

Rashid, R.A. (2003). The employment of language learning strategies among university students. Kertas Kerja 2nd International Seminar on Learning and Motivation. Universiti Utara Malaysia, 13-15 October.

Rouyan, N.M. (2006). Strategi pembelajaran bahasa dalam pembelajaran bahasa Arab: Kajian di KUSZA. [Language learning strategies in Arabic language learning: A study in KUSZA]. Bachelor dissertation. Bangi: Universiti Kebangsaan Malaysia.

Rumelhart, D. E. (1977). Toward an interactive model of reading. Attention and Performance 6, 573-603

Rye, J. 1982. Cloze procedure and the teaching of reading. London: Heinemann Educational Book.

Samah, R. (2008). Pendekatan pengajaran Bahasa Arab di USIM. [ Approach to teaching Arabic at USIM] International Conference on Language Teaching and Learning, Universiti Multimedia.

Samah, R. (2009). Isu pembelajaran Bahasa Arab di Malaysia. [The issue of learning Arabic in Malaysia.] Nilai: USIM

Sjahrony, A., Lubis, M.A., \& Yusoff, N.M.R.N. (2017). Kepentingan kebolehbacaan buku teks dalam dunia pendidikan. [The importance of textbook readability in the world of education] ASEAN Comparative Education Research Journal on Islam and Civilization, 1(1), 25-40. 
Teh, K.S.M., \& Embi, M.A. (2009). Korelasi strategi dengan motivasi dalam pembelajaran Bahasa Arab. [Correlation of strategy with motivation in learning Arabic.]. Jurnal Pendidik dan Pendidikan, 24, 109-123.

Teh, K.S.M., \& Embi, M.A. (2010). Strategi pembelajaran bahasa. [Language learning strategies.]. Kuala Lumpur: Universiti Malaya.

Teh, K.S.M., Yusoff, N.M.R.N., Embi, M.A., \& Mahamod, Z. (2009). Hubungan penggunaan strategi pembelajaran bahasa dengan tahap penguasaan bahasa Arab. [The relationship between the use of language learning strategies and the level of Arabic language proficiency]. Journal of Islamic and Arabic Education, 1(1), 41-56.

Urquhart, A. H. \& Weir, C. J. (1998). Reading in a second language: Process, product, and practice. London and New York: Longman.

Yusoff, M. (1999). Strategi pengajaran bacaan dan kefahaman. [Reading and comprehension teaching strategies] Kuala Lumpur: Dewan Bahasa dan Pustaka.

Yusoff, N.M.R.N., \& Ghani, K.A. (1999). Faktor-faktor yang mempengaruhi keberkesanan penguasaan kemahiran kefahaman bacaan bahasa Arab di kalangan pelajar-pelajar sekolah menengah agama: Kajian di negeri Kelantan. [Factors influencing the effectiveness of the mastery of Arabic reading comprehension skills among religious secondary school students: A study in the state of Kelantan]. Laporan Projek, Fakulti Pendidikan, Universiti Kebangsaan Malaysia.

Yusoff, N.M.R.N., \& Ghani, K.A. (2008). Penggunaan alat bantu mengajar dan hubungannya dengan pencapaian kemahiran mendengar Bahasa Arab. [The use of teaching aids and its relationship with the achievement of Arabic listening skills]. Jurnal Teknologi, 49, 141-154.

Zimmerman, B.J., \& Martinez-Pons, M. (1990). Student differences in selfregulated learning: Relating grade, sex \& giftedness to self-efficacy \& strategy use. Journal of Educational Psychology, 82(1), 51-59. 